Article

\title{
Analysis of the Pyroclastic Flow Deposits of Mount Sinabung and Merapi Using Landsat Imagery and the Artificial Neural Networks Approach
}

\author{
Prima Riza Kadavi ${ }^{1}$, Won-Jin Lee ${ }^{2}$ and Chang-Wook Lee ${ }^{1, *}$ \\ 1 Division of Science Education, Kangwon National University, 1 Kangwondaehak-gil, Chuncheon-si, \\ Gangwon-do 24341, Korea; rizakadavi@gmail.com \\ 2 Earthquake Volcano Research Center, Korea Meteorological Administration, 61 16-Gil, Yeouidaebang-ro, \\ Dongjak-Gu, Seoul 07062, Korea; wjleeleo@korea.kr \\ * Correspondence: cwlee@kangwon.ac.kr; Tel.: +82-33-250-6731
}

Received: 25 July 2017; Accepted: 8 September 2017; Published: 11 September 2017

\begin{abstract}
Volcanic eruptions cause pyroclastic flows, which can destroy plantations and settlements. We used image data from Landsat 7 Bands 7, 4 and 2 and Landsat 8 Bands 7, 5 and 3 to observe and analyze the distribution of pyroclastic flow deposits for two volcanos, Mount Sinabung and Merapi, over a period of 10 years (2001-2017). The satellite data are used in conjunction with an artificial neural network method to produce maps of pyroclastic precipitation for Landsat 7 and 8 , then we calculated the pyroclastic precipitation area using an artificial neural network method after dividing the images into four classes based on color. Red, green, blue and yellow were used to indicate pyroclastic deposits, vegetation and forest, water and cloud, and farmland, respectively. The area affected by a volcanic eruption was deduced from the neural network processing, including calculating the area of pyroclastic deposits. The main differences between the pyroclastic flow deposits of Mount Sinabung and Mount Merapi are: the sediment deposits of the pyroclastic flows of Mount Sinabung tend to widen, whereas those of Merapi elongated; the direction of pyroclastic flow differed; and the area affected by an eruption was greater for Mount Merapi than Mount Sinabung because the VEI (Volcanic Explosivity Index) during the last 10 years of Mount Merapi was larger than Mount Sinabung.
\end{abstract}

Keywords: Sinabung eruption; Merapi eruption; pyroclastic flow deposits; Landsat imagery; artificial neural network

\section{Introduction}

Remote sensing research has used multispectral remote sensing imagery to provide additional data, proving to be a valuable source of spatio-temporal data for some applications. Applications that are widely used are: land cover classification, detection catch archeology, extracting spatial features and classification in a residential area, the extraction of the street, the estimation of urban sprawl automatic mapping feature flow, classification and feature extraction transport, mapping snow cover and the evaluation of geomorphological features [1,2].

Land cover assessment (LC) is very important in planning, monitoring and sustaining the utilization of natural resources. LC has a direct impact on water, atmospheric and soil erosion and is therefore directly related to many globally-important environmental issues [3]. Appropriate knowledge, updated and temporal, about LC is very important to address the issue of unplanned development, environmental degradation, loss of wildlife habitat and depletion of primary agricultural and forest land [4]. Therefore, it is important to evaluate and monitor the LC dynamics resulting from anthropogenic activities and natural phenomena to plan, monitor and sustain the utilization of natural resources [5]. 
In this study, land cover assessment is used to see the distribution of volcanic eruptions' deposits that may be dangerous to the surrounding area when the eruption occurs. The volcano is a naturally-formed entity on the surface of the Earth that occupies an area and displays volcanism. An eruption is the discharge of magma from within the Earth and can be divided into three types: explosive, effusive and hot spot eruptions. The type of eruption that occurs is influenced by many factors such as magma viscosity, the gas content of the magma, the influence of groundwater and the depth of the magma chamber [6]. The products ejected by volcanic eruptions, which are often catastrophic, can be captured by satellite, optical and radar sensors. Remote sensing images can be utilized to detect the spread of eruptive fumes associated with volcanic eruptions that spread in the atmosphere, pyroclastic deposits, incandescent lava, lahar distribution and dome deformation [7].

We analyze the evaluation of volcano hazard, especially pyroclastic deposit, using land classification with Landsat imagery data and the artificial neural network approach. Several different approaches to the evaluation of volcano hazards can be found in the current literature, including direct and indirect heuristic approaches and deterministic, probabilistic and statistical approaches. Lee et al. (2015) summarized the many analyses of volcano activity based on remote sensing and GIS techniques [8]. Recently, studies on volcano activity assessment made use of remote sensing, and many applied probabilistic models such as satellite imagery. We used land classification in satellite imagery using an artificial neural network method to analyze the area affected by an eruption. Lee at al. (2003) showed that the most frequently-used neural network method is the backpropagation learning algorithm, a learning algorithm of a multilayered neural network that consists of an input layer, hidden layers and an output layer [9]. Many experiments have shown that multilayered neural networks are more accurate for land cover classification than traditional statistical methods [10-13].

\section{Study Area}

Indonesia is a country located in the ring of fire, an area of frequent geological disasters, including earthquakes, volcanoes, flash floods, landslides and tsunamis. These disasters are harmful, destructive and result in a huge loss of life. The most frequent disaster in Indonesia is a volcanic eruption. Indonesia currently has 129 active volcanoes, and 70 volcanoes have erupted in the last 400 years. The area of land threatened by a volcanic eruption in Indonesia is $16,670 \mathrm{~km}^{2}$, and around 5,000,000 lives are threatened by volcanic eruptions [14].

There have been several volcanic eruptions in Indonesia (Figure 1a) in the last 10 years. The focus of this research is Mount Sinabung (Figure 1b) and Merapi (Figure 1c), the eruptions of which have caused many casualties. The eruption of Merapi in 2010 was the largest eruption in the last 10 years and killed 347 people. Mount Sinabung has erupted two times in the last 10 years in 2010 and 2013-2017. The period of eruption of 2013 is still ongoing and has killed 16 people [14].

Mount Sinabung is in the Karo Highlands, Karo District, North Sumatra Province, Indonesia. The geographical position of the peak of Mount Sinabung is $3^{\circ} 10^{\prime}$ north latitude and $98^{\circ} 23.5^{\prime}$ east longitude. The height of Mount Sinabung is $2460 \mathrm{~m}$ above sea level, and its volcano type is a stratovolcano [14]. Mount Sinabung was dormant for 400 years, from 1600-2010 CE. Mount Sinabung finally erupted in 2010, an activity that was predicted from the three earthquakes that struck Sumatra. The earthquakes measured 8.8, 7.9 and 8.4 on the Richter scale and struck in 2005, 2007 and 2007, respectively [15].

Mount Merapi is located on the border of four districts; Sleman, Yogyakarta and Magelang, Boyolali and Klaten, in Central Java Province. Its geographical position lies at $7^{\circ} 32^{\prime} 30^{\prime \prime}$ north latitude and $110^{\circ} 26^{\prime} 30^{\prime \prime}$ east longitude. Based on its tectonic order, the mountain is located in a subduction zone, where the meeting of the Indo-Australian and Eurasian Plates controls the volcanism in Sumatra, Java, Bali and Nusa Tenggara. The height of Mount Merapi is $2986 \mathrm{~m}$ above sea level, and its type is a stratovolcano [14]. Mount Merapi is a very active volcano mountain. Since 1600, Merapi volcano has erupted more than 80 times, and an eruption occurs on average every $4-5$ years. Merapi is a volcano 
cone composed of andesitic-basaltic magma with silica $\left(\mathrm{SiO}_{2}\right)$ content ranging from $52-56 \%$. The top morphology is characterized by a horseshoe-shaped crater, in which lava domes grow [16-19].

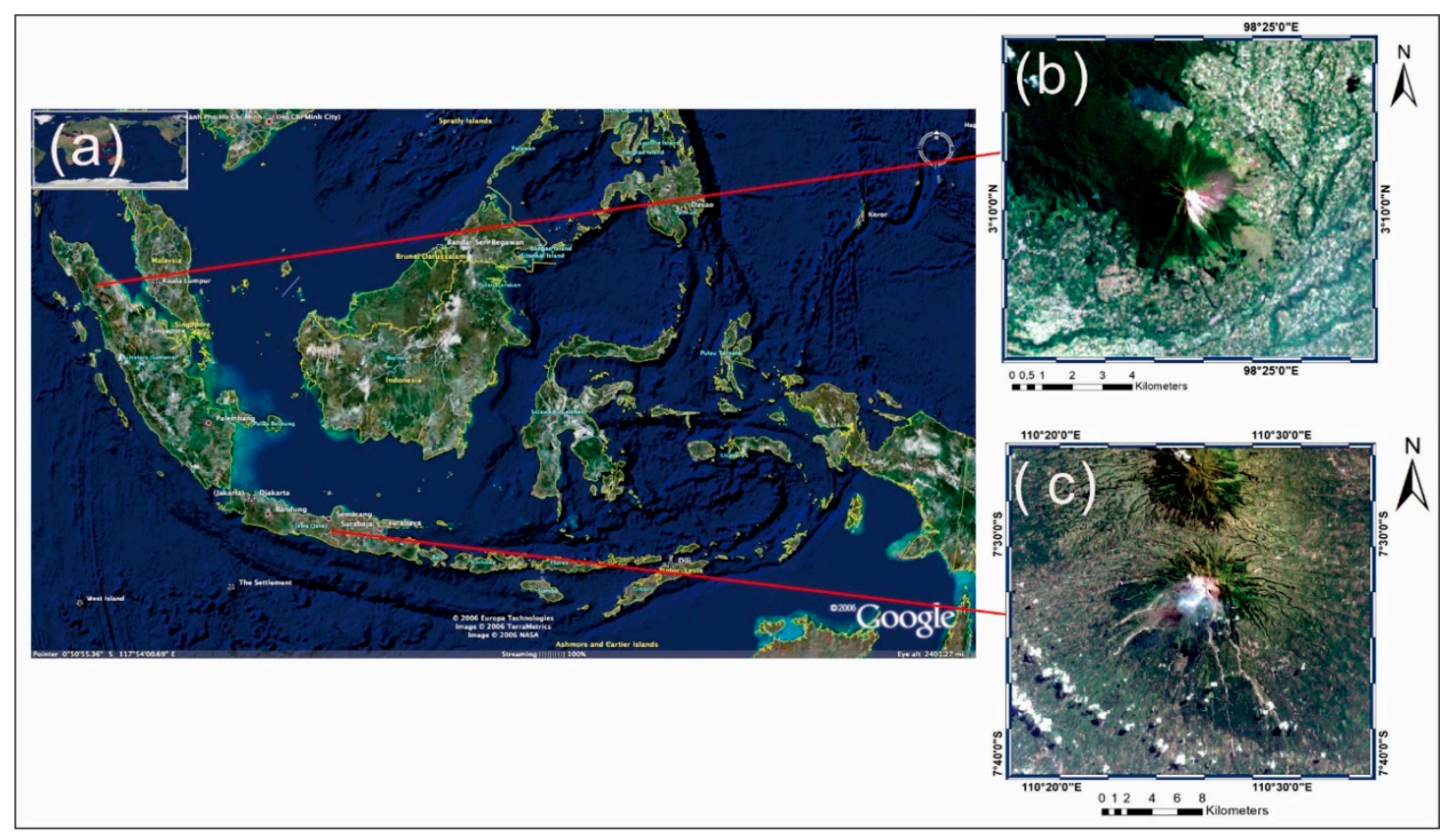

Figure 1. Map of Indonesia using Google Maps (a); location of Mt. Sinabung (b) and Merapi (c) on Sumatra and Java Islands from USGS earth explorer website [20].

\section{Data}

A pyroclastic flow inundation map can be generated by field surveys from the crater rim to the furthest extent of the pyroclastic flow after a volcanic eruption. However, a field survey in an active volcano can be dangerous because of the exposure to hazardous gases and sudden activity. In contrast, remote sensing techniques are a useful tool for generating pyroclastic flow deposit maps, which provide a safe, cost-effective alternative to field mapping.

A Landsat image is a picture of the surface of the Earth taken from outside the atmosphere at an altitude of approximately $818 \mathrm{~km}$ from the Earth's surface, on a scale of 1:250,000. Each Landsat image covers an area of $185 \mathrm{~km}^{2}$ so that the aspect of a large object can be identified without exploring all of the surveyed areas [21]. Each color in the satellite image has a meaning; a color on the image indicates whether a reflection value corresponds to vegetation, aquatic bodies or a body of the Earth's surface rock [22]. Therefore, geological interpretation of the Landsat image is based on the difference between the reflection values [23].

This study used satellite data from Landsat 7 ETM+ and Landsat 8. Landsat 7 ETM+ was used to see the changes of pyroclastic deposits from 2007 to 2012, while Landsat 8 was used to see changes in pyroclastic deposits from 2013 to 2017. However, the Landsat 7 ETM+ data suffer from the scan line corrector (SLC)-off phenomenon because of the failure of the SLC in the ETM+ instrument. These images can be restored by gap-filling the scan line using one-dimensional interpolation without any other supplementary data with the gap interpolation and filtering technique [24].

The Landsat 7 and Landsat 8 image data from Mount Sinabung and Mount Merapi were taken from USGS earth explorer website [20] using RGB Bands 7, 4 and 2 to see the pyroclastic deposit in Landsat 7 and RGB Bands 7, 5 and 3 to see the pyroclastic deposits in Landsat 8 (Figures 2 and 3). Landsat image data are taken annually to analyze changes in pyroclastic deposit. Landsat images were selected based on their image quality. Several parameters were used to assess the quality of Landsat 
images, including sunlight and cloud cover in the image of the object of research. Based on these parameters, data selection is performed in different months and dates in each year.

We select the Landsat image data representing data before eruption and after eruption to see the difference in pyroclastic deposit area of Mount Sinabung and Merapi. For Mount Sinabung, we chose Landsat image data taken 7 February 2007 as data before eruption, 17 November 2011 as data after the first eruption, 1 July 2016 as data after the second eruption and 28 July 2017 as current pyroclastic deposit data. For Mount Merapi, we chose Landsat image data taken 16 June 2007 as data before eruption, 10 May 2011 and 2 November 2014 as data after the big eruption in 2010 and 23 May 2017 as current pyroclastic deposit data.
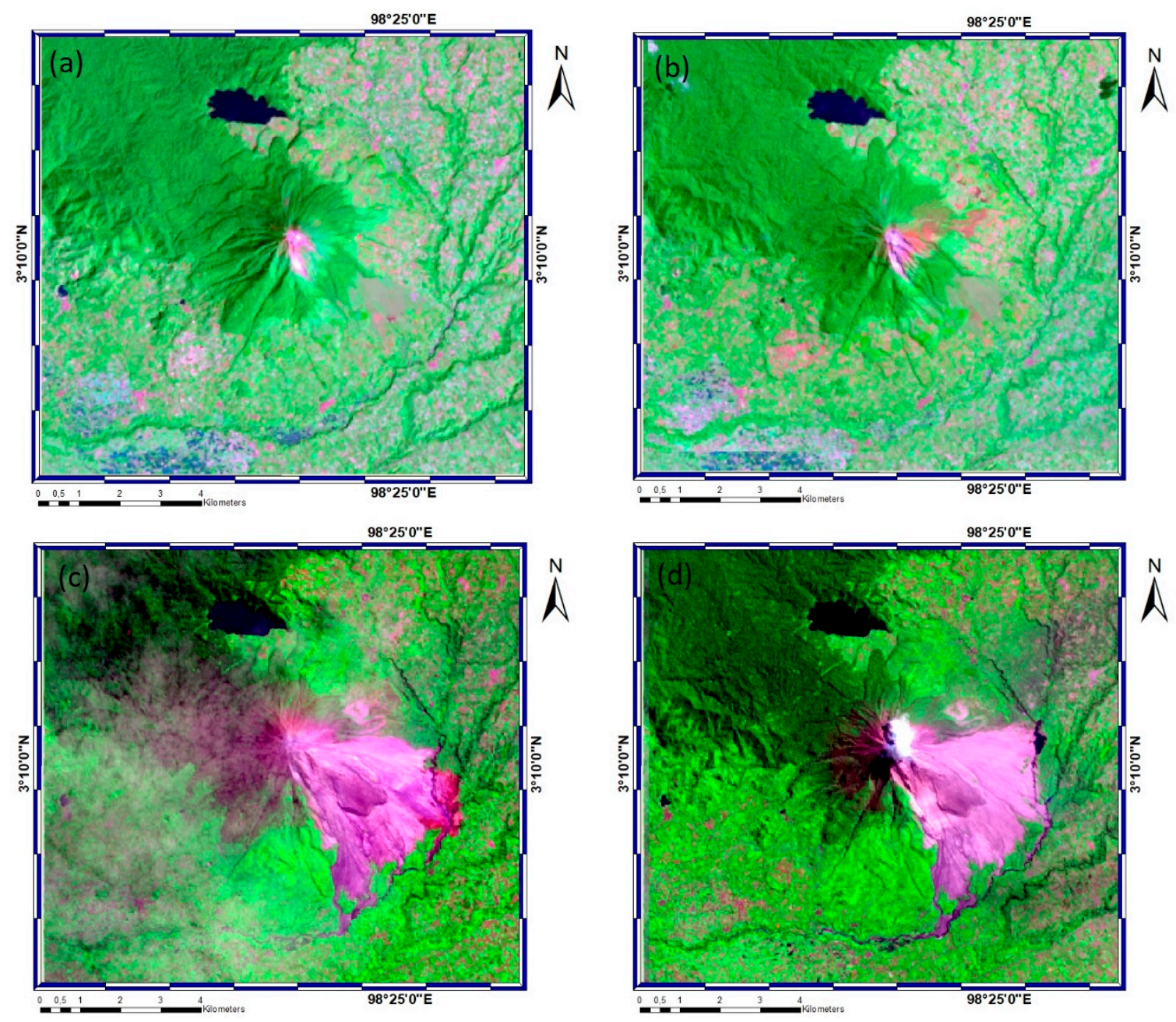

Figure 2. Landsat 7 (Bands 7, 4 and 2) and Landsat 8 (bands 7, 5 and 3) imagery data of Mount Sinabung taken in the year shown below each image. We can see the changes of pyroclastic deposits of Mount Sinabung from before eruption (a) 7 February 2007, after the first eruption on (b) 17 November 2011, after the second eruption on (c) 7 July 2016, and current pyroclastic deposits on (d) 28 July 2017, marked with grey color in the middle of the image. 

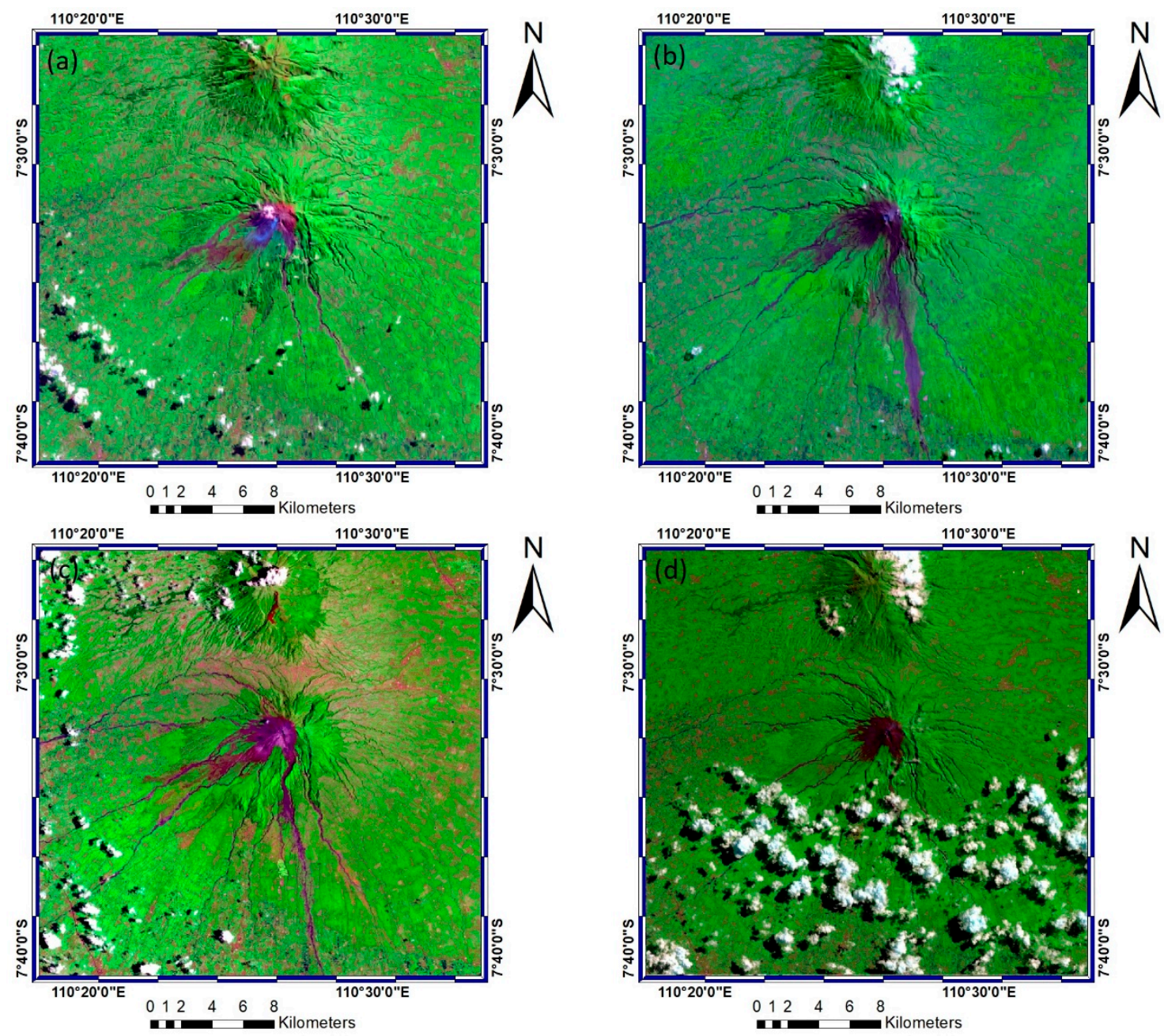

Figure 3. Landsat 7 (Bands 7, 4, 2) and Landsat 8 (Bands 7, 5, 3) imagery data of Mount Merapi taken in the year shown below each image. We can see the changes of pyroclastic deposits of Mount Merapi from before eruption on (a) 16 June 2007, and also during the time after the big eruption in 2010, which can see on (b) 10 May 2011 and (c) 2 November 2014, and current pyroclastic deposits on (d) 23 May 2017, marked with dark grey color in the middle of the image.

\section{Methodology}

A neural network model belongs to the branch of artificial intelligence generally referred to as artificial neural networks (ANNs). ANNs teach a system to execute a task, instead of using a computational programming system to do defined tasks. To perform such tasks, an artificial intelligence system (AI) is generated; a pragmatic model that can quickly and precisely find the patterns buried in data that represent useful knowledge. Neural networks are one example of these AI models. In the area of medical diagnosis relationships with dissimilar data, artificial intelligence is one of the most available techniques [25].

In this method, the analyst first determines some training area (sample area) on the image as a class of the appearance of a particular object. This determination is based on the analyst's knowledge of the region of land cover areas. The pixel values in the sample area are then used by computer software as the key to recognizing other pixels. Areas that have similar pixel values are entered into predefined classes [10]. Therefore, in this method, the system first identifies the class of information, and this class is then used to determine the spectral class that represents the class of information.

An ANN is a mathematical model that has been applied for the identification, modeling, optimization, forecasting, prediction and control of complex systems [26,27]. It can be trained for 
performing a particular task based on available empirical data [28]. ANN is a nonparametric approach that has advantages over statistical classification techniques and has been widely used in different LC studies in recent years $[29,30]$. The NN classifier adopted in this study is a nonlinear layered feed-forward model with standard backpropagation for supervised learning. To perform the ANN using ENVI software, the logistic activation method was used, and one hidden layer was selected. The training threshold contribution and training momentum fields were set to a value of 0.9. Finally, the training rate field, training RMS exit criteria field and number of training iterations were set to values of $0.2,0.1$ and 100 , respectively.

The links with the neurons located in the so-called hidden neuron layer then take different weights and are trained depending on the required output, thus modeling complex relationships among variables [31]. The system requires feed-forward and backpropagation processes to allow the network to be trained. The visualization of this stage is accomplished through error analysis. If the error becomes smaller and asymptotic, the network will be ready to receive new input data and predict the output [32].

The ANN models used in this study are of the multilayer perceptron ANN type [33]. The architecture is as shown in Figure 4. The input layer is Region 1 (red color as pyroclastic deposits), Region 2 (blue color as water), Region 3 (green color as forest) and Region 4 (yellow color as farmland). In each case, the training of the proposed network was performed with a backpropagation algorithm, which is a supervised learning procedure. It uses the method of gradient descent for minimizing the global quadratic error of the output calculated by the network [32].

\section{\begin{tabular}{|ll|}
\hline Input Layer Hiden Layer Output Layer \\
\hline
\end{tabular}}

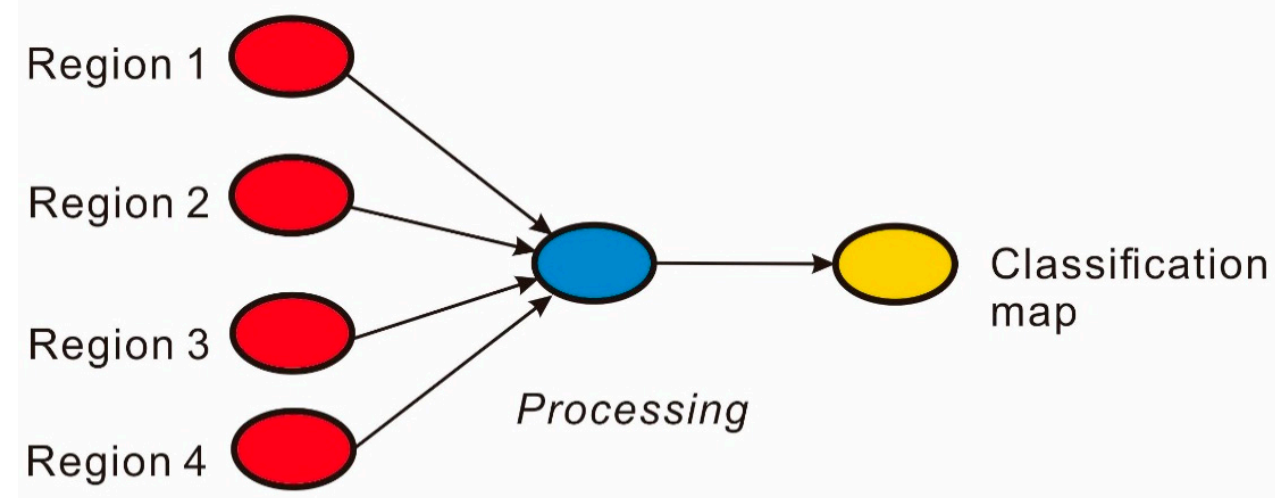

Figure 4. Artificial neural network model used for data analysis. Input layer data Regions 1-4, which are select in ENVI. The output layer is the classification map.

\section{Result}

\subsection{Classification of Landsat Images}

The pyroclastic dimension area was analyzed using supervised classification using the artificial neural network approach in the ENVI program. We used the gap-filled Landsat data to delineate the pyroclastic deposit surrounding areas through supervised classification. We established four classes for Mount Sinabung and Mount Merapi. The focus of this study is the pyroclastic deposits, which are marked as red. The classes used on Mt. Sinabung are forest (green), farmland (yellow), water and shadow (blue) and pyroclastic deposit (red). Mt. Merapi is divided into forest (green), farmland (yellow), cloud (blue) and pyroclastic deposit (red).

Land classification on Mount Sinabung using the artificial neural network approach is shown in Figure 5. The land classification is divided into four classes based on its color: green as forest, 
yellow as farmland, blue as water and shadow and red as pyroclastic precipitate. We selected Landsat image data in this study taken on 7 February 2007 as data before eruption, 17 November 2011 as data after the first eruption, 1 July 2016 as data after the second eruption and 28 July 2017 as current pyroclastic deposit data. Based on the supervised classification maps of Mt. Sinabung (Figure 5), the pyroclastic flow depositional area was primarily in the southern region of Mt. Sinabung before the first eruption in 2010. However, the pyroclastic flow deposit migrated to the eastern part of the volcano after the 2010 eruption (Figure 5a,b). The next eruption was in 2013-2017 (Figure 5b,c), and from the land classification data, it can be seen that after the second eruption on 1 July 2016, there was a very big change in the pyroclastic deposits of Mount Sinabung. The pyroclastic precipitate flows to the southeast and extends downward with a shape resembling a landslide. On 28 July 2017, it was seen that pyroclastic deposits did not change too much from the previous year.
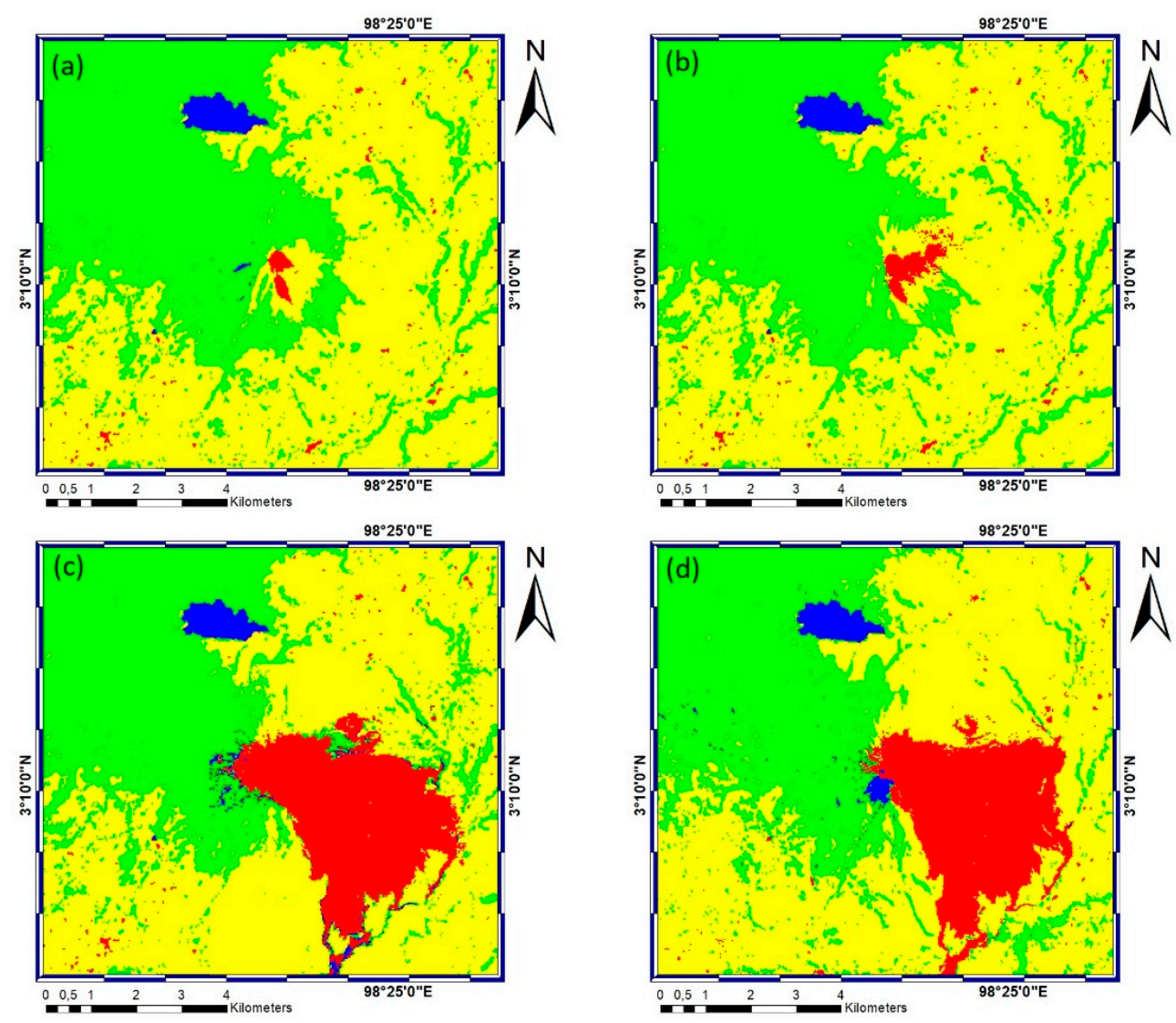

\section{Legend}

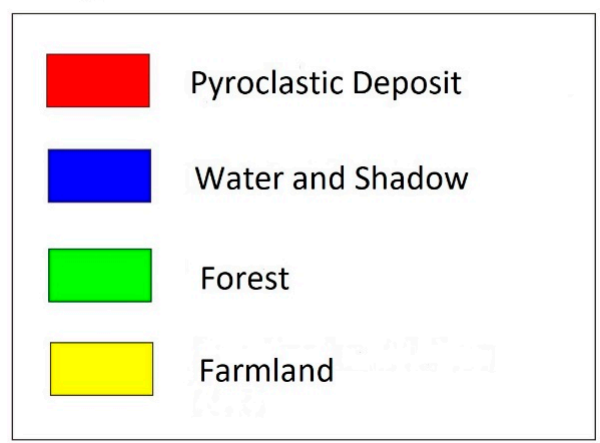

Figure 5. Supervised classification maps from ANN processing in the ENVI program of the Mount Sinabung Landsat Imagery taken on: (a) 7 February 2007; (b) 17 November 2011; (c) 1 July 2016; and (d) 28 July 2017. 
Land classification on Mount Merapi using the artificial neural network approach is shown in Figure 6. The land classification is divided into four classes based on its color: green as forest, yellow as farmland, blue as cloud and red as pyroclastic precipitate. We selected Landsat image data in this study taken on 16 June Landsat 2007 as data before eruption, 10 May 2011 and 2 November 2014 as data after the big eruption in 2010 and 23 May 2017 as current pyroclastic deposits. Based on the supervised classification maps of Mount Merapi (Figure 6), the pyroclastic flow depositional area primarily existed in the southwestern region before the eruption in 2010. However, the pyroclastic flow deposit migrated to the southern part of the volcano after the 2010 eruption.
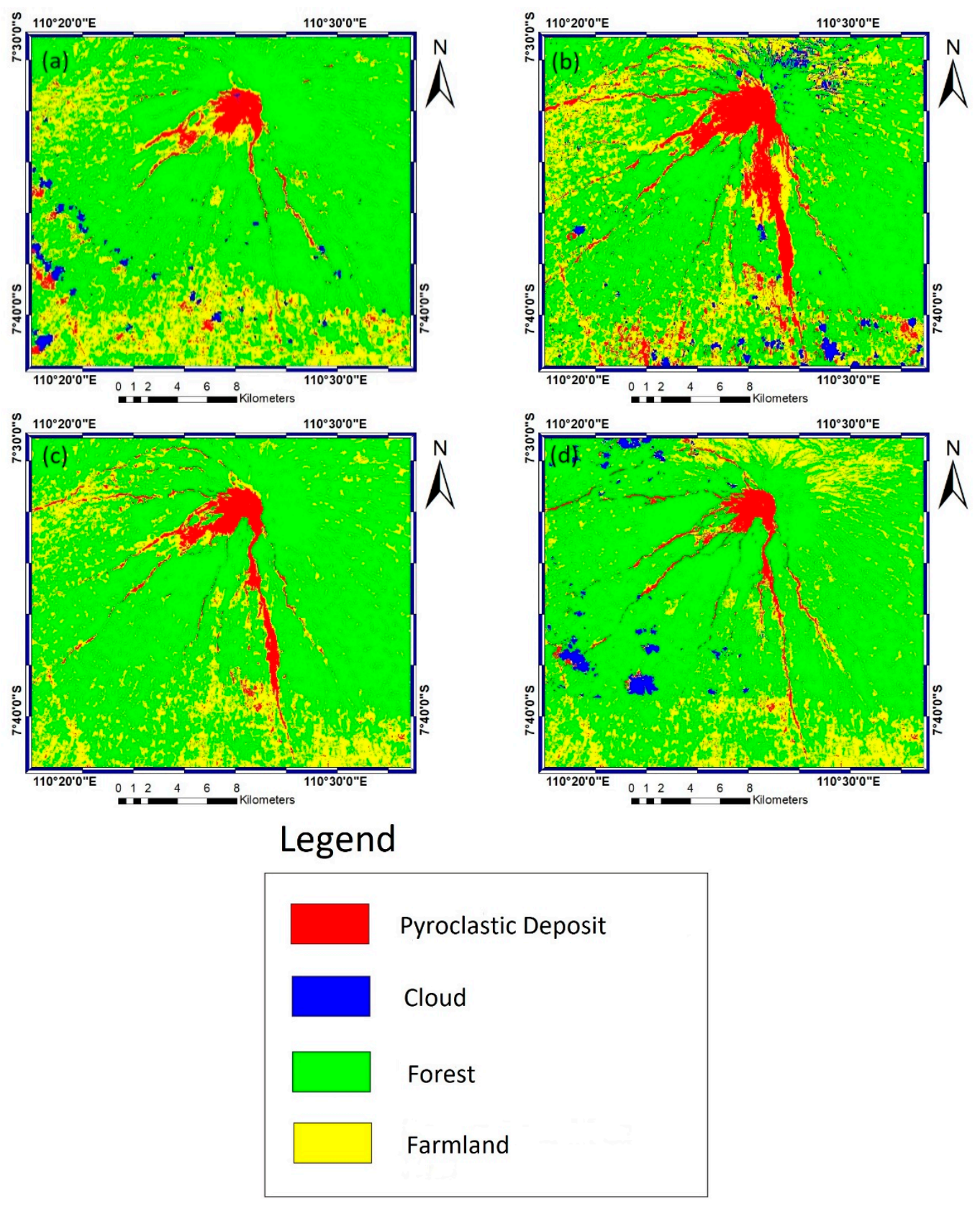

Figure 6. Supervised classification maps using ANN processing in the ENVI program of Mount Merapi Landsat imagery data taken on: (a) 16 June 2007; (b) 10 May 2011; (c) 2 November 2014; and (d) 23 May 2017. 


\subsection{Time Series Analysis of Pyroclastic Deposit}

Pyroclastic deposits area are constantly changing after an eruption, and therefore, time series analysis is needed to compare the area of pyroclastic deposits in each year. Time series analysis of pyroclastic deposit land classification with Landsat imagery data is used to calculate the area of pyroclastic deposits. We calculate the area of the pyroclastic deposits using ArcMap. The data of the land classification map with a multilayer format are used to calculate pixels in each class [34], because the concern of this research is the pyroclastic deposit, so we only calculate red pixels, which means pyroclastic deposit on the land classification map. The Landsat image has a resolution of $30 \times 30 \mathrm{~m}$, so we just multiply the number of pixels by the resolution of the Landsat image to get the area of pyroclastic deposits.

The pyroclastic deposits on Mt. Sinabung increased after the eruption in 2010. Since Mt. Sinabung has been highly active since 2010, the pyroclastic deposit area changes every year. We can see the change of the pyroclastic deposit of Mt. Sinabung each year based on Table 1 . Before the eruption, pyroclastic deposits were calculated as $0.3807 \mathrm{~km}^{2}$ in 2007 . The area of pyroclastic deposits increased in 2011 due to the eruption in 2010 to $1.5066 \mathrm{~km}^{2}$. The increase of pyroclastic precipitate in 2011 was not too big because the eruption that occurred in 2010 was a small eruption. Then, in 2013-2017, the second eruption occurred, and in 2016, the pyroclastic deposit area due to the second eruption of Mount Sinabung in the last ten years increased very significantly to $20.5911 \mathrm{~km}^{2}$; this can be seen in Figure 7. The current pyroclastic deposit area of Mount Sinabung is estimated at $18.4572 \mathrm{~km}^{2}$.

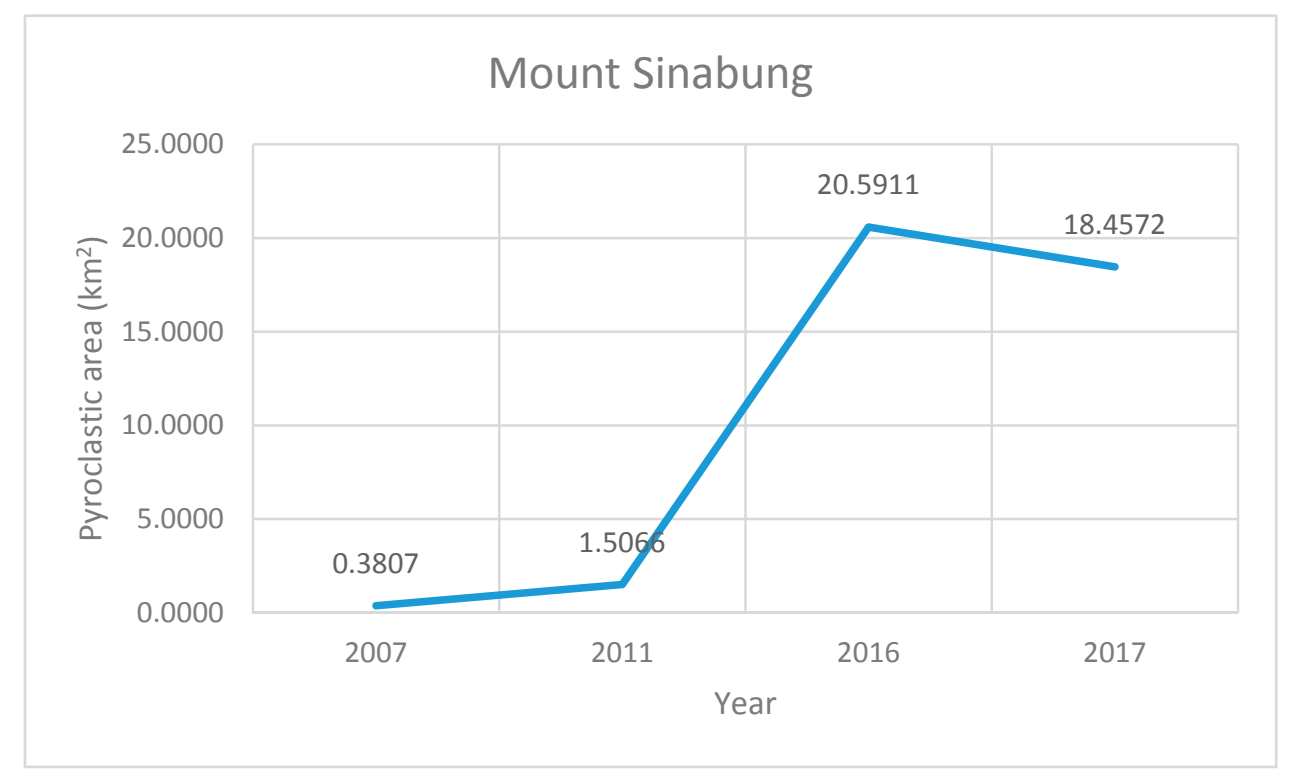

Figure 7. Time series of pyroclastic flow deposits for Mount Sinabung.

Table 1. Time series of pyroclastic flow deposits.

\begin{tabular}{cccc}
\hline \multirow{2}{*}{ Mount Sinabung No. } & Year & \multicolumn{2}{c}{ Pyroclastic Deposit Area } \\
\cline { 3 - 4 } & & Pixel & $\mathbf{k m}^{\mathbf{2}}$ \\
\hline 1 & 2007 & 423 & 0.3807 \\
2 & 2011 & 1674 & 1.5066 \\
3 & 2016 & 22,879 & 20.5911 \\
4 & 2017 & 20,508 & 18.4572 \\
\hline
\end{tabular}

Mount Merapi erupted in 2006; thus, the pyroclastic deposit of Mount Merapi was still high in 2007, as it was calculated to be $16.443 \mathrm{~km}^{2}$ in Table 2. In 2010, Merapi erupted with VEI (Volcanic Explosivity 
Index) 4. Therefore, much volcanic material was ejected and caused damage. The pyroclastic deposits caused by the eruption in 2010 were very big, increasing two-fold from previous eruptions (Figure 8). We can calculate the pyroclastic deposit of by the 2010 eruption by $2011 \mathrm{data}$; it is $38.2536 \mathrm{~km}^{2}$. After the big eruption of 2010, the pyroclastic deposits area was decreased, calculated for Landsat 2014 as $20.5911 \mathrm{~km}^{2}$. The current pyroclastic deposit area of Mount Sinabung is estimated at $18.4572 \mathrm{~km}^{2}$.

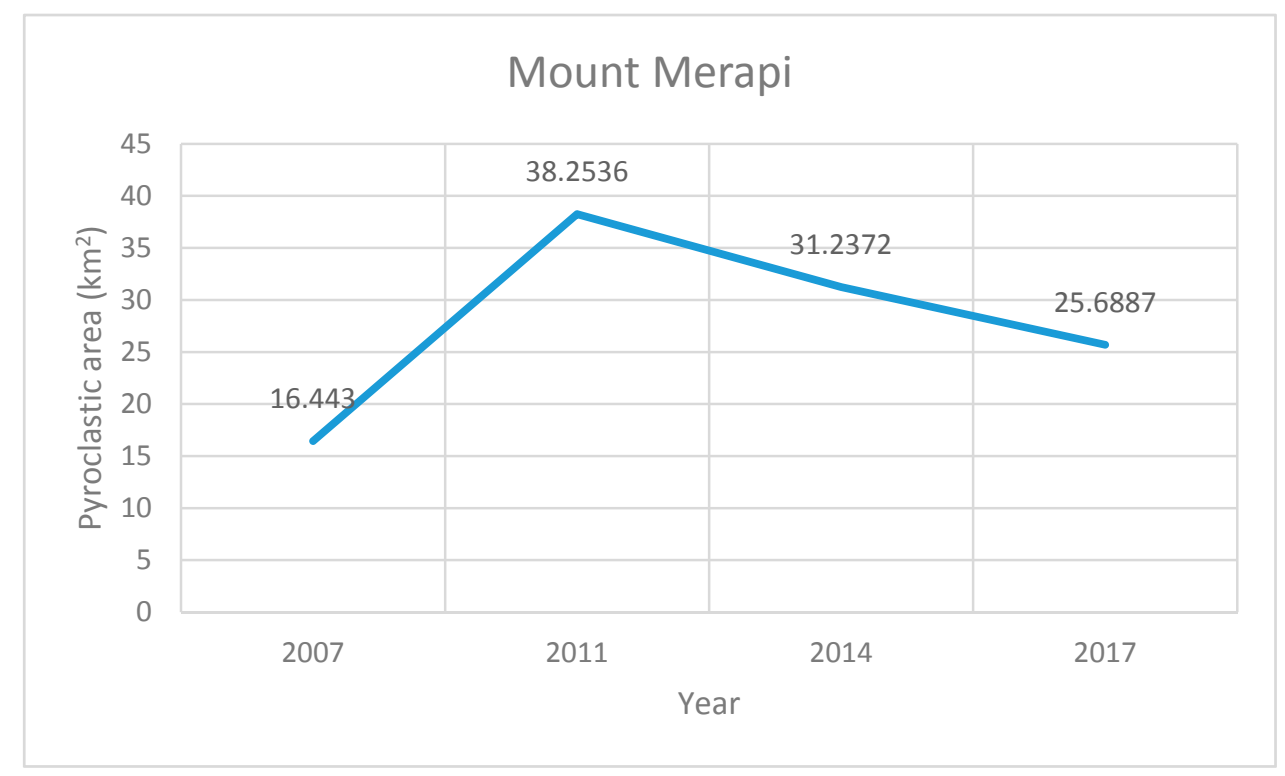

Figure 8. Time series of pyroclastic flow deposit for Mount Merapi.

Table 2. Time series of pyroclastic flow deposit.

\begin{tabular}{cccc}
\hline \multirow{2}{*}{ Mount Merapi. No } & Year & \multicolumn{2}{c}{ Pyroclastic Deposit Area } \\
\cline { 3 - 4 } & & Pixel & $\mathbf{k m}^{\mathbf{2}}$ \\
\hline 1 & 2007 & 18,270 & 16.443 \\
2 & 2011 & 42,504 & 38.2536 \\
3 & 2014 & 34,708 & 31.2372 \\
4 & 2017 & 28,543 & 25.6887 \\
\hline
\end{tabular}

\section{Discussion}

The supervised classification neural network analysis was used to view and calculate the area of pyroclastic flow deposits. From the Landsat imagery data, differences in appearance can be seen between pyroclastic flow deposits, forests, lakes and plantations. Landsat image data were used as an object for supervised neural network classification analysis. The supervised neural network classification divides the area based on the pixels that have been selected according to the class. The results of the supervised neural network analysis show that there are differences in the distribution of pyroclastic flow deposits between Mount Merapi and Mount Sinabung. The apparent differences in the Landsat imagery data that have been found by classification by the supervised neural network are the direction of flow, the area of deposit and the distribution of pyroclastic flow deposits. The differences in the distribution of pyroclastic flow deposits between Mount Sinabung and Mount Merapi were caused by several influential factors, such as the formation of volcanoes, regional geological conditions, volcano magmatic properties, volcanic type, lava domes and the Volcanic Explosivity Index.

The geological conditions of Sumatra affect the formation of Mt. Sinabung. The outline of Sumatra Island consists of three tectonic systems, namely the Sumatra Subduction System, the Mentawai Fault 
system and the Sumatra Fault System. Based on the geological reconstruction by Robert Hall (2000) [35], the initial formation of the Sumatra region began $\sim 50$ million years ago (early Eocene). There are at least 19 C-section segments, each with lengths of $\pm 60-200 \mathrm{~km}$, in the Sumatra Fault System, which has a total length of $\pm 1900 \mathrm{~km}$. Lake Toba on the island of Sumatra is evidence of a supervolcano and is the remains of the largest eruptions of Caldera Crescent (scale: 8 VEI).

The eruptions of Mount Sinabung eject many volcanic materials, one of which is pyroclastic flow. The pyroclastic flow deposits of Mount Sinabung spread to the southeast, tend to widen and are not transported far from the crater of Mount Sinabung. These characteristics result from the acid-intermediate (andesitic-rhyolitic) [17] magma of Mount Sinabung, which tends to be thick and prevents the pyroclastic flow deposit from being transported far. The other factor is due to the shape of the slopes of Mt. Sinabung, where the pyroclastic flows and the direction of the river in Sinabung valley are almost perpendicular. Mount Sinabung is a Type B mountain, which means there was no track record of eruption before it erupted in 2010 [14]. The eruption of 2010 was a phreatic-type eruption, as defined by the presence of volcanic dust. A phreatic eruption is the process of magma escaping to the surface because of the influence of steam caused by the direct or indirect interaction between water and magma [36]. The second eruption of Mount Sinabung was larger than that in 2010, which could have been caused by the formation of an old dome on Mount Sinabung after the first eruption. The material ejected in the next eruption mixed with the material on the surface or around the crater, destroying the already formed lava dome and forming a new lava dome. The eruptions of Mount Sinabung are generally rated as VEI 2, which means the eruption is relatively small [37]. However, the eruptions are continuous and interfere with the activity of the residents. A larger eruption is probable to occur since Sinabung is located in the Semangko Fault Zone, the largest fault on Sumatra Island.

Based on seismic data, Mount Merapi is estimated to have a magma pouch because no seismic data from inside the seismic zone exist, indicating that there is a soft material between harder materials in the seismic zone. This soft material is thought to be the magma pocket of Mount Merapi [19]. This hypothesis is supported by the fact that the temperatures around the top of the Woro and Gendol plates can reach $830{ }^{\circ} \mathrm{C}$, which means there is a sufficiently shallow source of heat. It is estimated that these magma pockets arise because of this basic fault, where magma can accumulate. This magma pocket is thought to act as a valve that slows the upward magma migration of the magma chamber. Therefore, the scale of the eruption is reduced [18]. The absence of an earthquake below $5 \mathrm{~km}$ strengthens the case for the existence of a magma kitchen at a depth of $\sim 8 \mathrm{~km}$, as proposed by Beaducel (1998) based on tiltmeter and GPS data modeling [6].

Mount Merapi erupts almost every five years because of the existence of magma pockets in the magma chamber of Merapi Volcano, which are likely to have been formed by a major eruption in the past. The major eruptions recorded on Mount Merapi in the 21st Century were in 2006 and 2010, with the 2010 eruption causing more than 350 casualties [14].

Landsat imagery data show that the 2010 eruption issued pyroclastic material from inside Merapi's crater that spread around the Mt. Merapi area. Landsat 8 image data using Bands 4, 3 and 2 in the natural view show that the direction of the pyroclastic flow was to the south and southwest and that Merapi's pyroclastic flow sediment tends to elongate because it is transported far from the peak. The long range of the flow could be caused by the valleys that run in the same direction as the slope, as well as the basaltic-andesitic (intermediate-base) magma type. This type of magma tends to be dilute and can be transported far, along with the outflow of pyroclastic flows from the eruption. Merapi's eruption type can be categorized as a weak volcanic type that is not so explosive, but pyroclastic flow almost always occurs after an eruption. The eruptive activity of Merapi can be seen to undergo a long process, from the initial lava dome formation to incandescent lava and hot clouds (pyroclastic flow). The eruption in 2010 had a strong VEI value of four, and lahar flows occurred in addition to a pyroclastic flow [16]. Lahar flows damage buildings and bridges because of their high speed and because they carry material such as stone and sand. In addition, volcanic ash is widely distributed, 
the high silica content of which makes it dangerous to breathe. The volcanic ash sediment can be seen in Landsat 7 imagery data from 2010.

\section{Conclusions}

Mount Sinabung first erupted in 2010 after a long break of over 400 years, and this first eruption was followed by a series of six eruptions between 2013 until 2016. The biggest eruption occurred in 2014 and had a VEI of two, causing $~ 16$ deaths and the destruction of farmland and residents' houses by pyroclastic flows. Mount Merapi erupts roughly every five years because of the high magma activity in its magma chamber, as well as the magma pocket that formed during a past eruption. We analyzed the differences in the pyroclastic deposit flows between Mt. Sinabung and Mt. Merapi, using Landsat 7 and 8 imagery with Bands 7, 4, 2 and 7, 5, 3, respectively, to see the pyroclastic precipitates and deposits of sand and rocks.

An artificial neural network method was used to analyze the pyroclastic precipitates and the pyroclastic precipitate area using Landsat imagery data taken annually from 2007 to 2017 for each volcano. The analysis showed that the pyroclastic sediment of Mount Sinabung spread to the east at the beginning of eruption and then widened to the southeast and south after the series of eruptions took place. The continuous eruption of Mount Sinabung caused the formation of pyroclastic deposits that accumulated around the body of the mountain. The pyroclastic sediment of Mount Sinabung tends to widen and is not transported far because of the direction of river flow on the mountain, which is not in the direction of the mountain's slope. In addition, the andesitic-rhyolitic (intermediate-acid) magma composition of Mount Sinabung prevents pyroclastic flow from being transported far, because the lava tends to be thick. In contrast, the pyroclastic flows of Mount Merapi flow to the south and to the southwest along the slope and river flow direction of Mount Merapi. Thus, the pyroclastic sediment of Mount Merapi does not accumulate much in the body of Merapi Volcano, but flows following the slope of the volcano. The composition of magma on Mount Merapi is also different from Mount Sinabung; Mount Merapi's magma is andesitic-basaltic (intermediate-base), so the flowing lava is thin and easily transported. Although the maximum VEI of Merapi is larger than that of Sinabung (VEIs of four and two, respectively), the pyroclastic precipitates of Mount Sinabung's eruption are wider than those of Mount Merapi ( $\sim 18$ and $\sim 17 \mathrm{~km}^{2}$, respectively).

Acknowledgments: This research was supported by the Basic Science Research Program through the National Research Foundation of Korea (NRF) funded by the Ministry of Science, ICT \& Future Planning (NRF-2015M1A3A3A02013416) and the Korea Meteorological Administration Research and Development Program under Grant KMIPA (2015-3071).

Author Contributions: Prima Riza Kadavi applied the artificial neural networks model for detecting pyroclastic flow deposit area and wrote the paper. Won-Jin Lee designed the volcanic experimental equation corresponding to volcano eruption. Chang-Wook Lee suggested the idea, organized the paper work and interpreted the results of volcanic activities. All of the authors contributed to the writing of each part.

Conflicts of Interest: The authors declare no conflict of interest.

\section{References}

1. Elhag, M. Quantification of Land Cover Changes Based on Temporal Remote Sensing Data for Ras Tarout Area, Saudi Arabia. Indian J. Geo-Mar. Sci. 2016, in press.

2. Elhag, M. Evaluation of Different Soil Salinity Mapping Using Remote Sensing Techniques in Arid Ecosystems, Saudi Arabia. J. Sens. 2016, 2016, 7596175. [CrossRef]

3. Koomen, E.; Stillwell, J. Modelling Land-Use Change; Springer: New York, NY, USA, 2007.

4. Anderson, J.R. A Land Use and Land cover Classification System for Use with Remote Sensor Data Vol 964; US Government Printing Office: Washington, DC, USA, 1976.

5. Ullah, S.; Farooq, M.; Shafique, M.; Siyab, M.A.; Kareem, F.; Dees, M. Spatial assessment of forest cover and land-use changes in the Hindu-Kush mountain ranges of north ern Pakistan. J. Mt. Sci. 2016, 13, 1229-1237. [CrossRef] 
6. Beauducel, F. Structures Mechanical Behaviour of Merapi Volcano, Java: A Methodological Approach of the Deformation Field. Ph.D. Thesis, University Denis Diderot Paris VII, Paris, France, 1998.

7. Lee, C.W.; Lu, Z.; Won, J.S.; Jung, H.S.; Dzurisin, D. Dynamic deformation of Seguam Volcano, Alaska, 1992-2008, from multi-interferogram InSAR processing. J. Volcanol. Geotherm. Res. 2013, 260, 43-51. [CrossRef]

8. Lee, C.W.; Kim, J.W.; Jung, H.S.; Lee, J.K.; Degrandpe, K.; Lu, Z. Volcanic activity analysis of Mt. sinabung in Indonesia using remote sensing and GIS techniques. In Proceedings of the Near-Surface Asia Pacific Conference, Waikoloa, HI, USA, 7-10 July 2015; pp. 150-153.

9. Lee, S.; Ryu, J.H.; Min, K.; Won, J.S. Landslide Susceptibility Analysis Using GIS and Artificial Neural Network. Earth Surf. Process. Landf. 2003, 28, 1361-1376. [CrossRef]

10. Canziani, G.; Perrati, R.; Marinelli, C.; Dukatz, F. Artificial Neural Network and Remote Sensing in the Analysis of the Highly Variable Pampean Shallow Lakes. Math. Biosci. Eng. 2008, 5, 691-711. [CrossRef] [PubMed]

11. Chen, K.; Yen, S.; Tsay, D. Neural classification of SPOT imagery through integration of intensity and fractal information. Int. J. Remote Sens. 1997, 18, 763-783. [CrossRef]

12. Saravanan, K.; Sasithra, S. Review on Classification Based On Artificial Neural Networks. Int. J. Ambient Syst. Appl. (IJASA) 2014, 2. [CrossRef]

13. Serpico, S.B.; Bruzzone, L.; Roli, F. An experimental comparison of neural and statistical non-parametric algorithms for supervised classification of remote sensing images. Pattern Recognit. Lett. 1996, 17, 1331-1341. [CrossRef]

14. Ministry of Energy and Natural Resources of the Republic of Indonesia. Available online: http:/ / www.vsi. esdm.go.id/ (accessed on 10 July 2017).

15. Lupi, M.; Miller, S.A. Short-lived tectonic switch mechanism for long-term pulses of volcanic activity after mega-thrust earthquakes. Solid Earth 2014, 5, 13-24. [CrossRef]

16. Hidayati, S.; Ishihara, K.; Iguschi, M.; Ratdomopurbo, A. Focal mechanism of volcano-tectonic earthquakes at merapi volcano, Indonesia. Indones J. Phys. 2008, 19, 75-82.

17. Iguchi, M.; Ishira, K.; Hendrasto, M. Learned from 2010 Eruptions at Merapi and Sinabung Volcanoes in Indonesia. Annu. Disaster Prev. Res. Inst. Kyoto Univ. 2011, 54, 185-194.

18. Ratdomopurbo, A.; Poupinet, G. An overview of the seismicity of merapi volcano (Java, Indonesia), 1983-1994. J. Volcanol. Geotherm. Res. 2000, 100, 193-214. [CrossRef]

19. Surono, M.; Jousset, P.; Pallister, J.; Boichu, M.; Buongiorno, M.F. The 2010 explosive eruption of Java's Merapi volcano-A '100-year' event. J. Volcanol. Geotherm. Res. 2012, 241-242, 121-135. [CrossRef]

20. Landsat 7 ETM+ and Landsat 8 Imagery. Available online: https:/ / earthexplorer.usgs.gov / (accessed on 10 July 2017).

21. Richards, J.A. Remote Sensing Digital Image Analysis; Springer: Berlin, Germany, 1999; Volume 240.

22. Eom, J.; Lee, C.W. Analysis on the Area of Deltaic Barrier Island and Suspended Sediments Concentration in Nakdong River Using Satellite Images. Korean J. Remote Sens. 2017, 33, 201-211.

23. Lee, S.; Kim, G.; Lee, C.W. Preliminary Study for Tidal Flat Detection in Yeongjong-do according to Tide Level using Landsat Images. Korean J. Remote Sens. 2016, 32, 639-645. [CrossRef]

24. Lee, C.W.; Cho, M.; Choi, Y.J. Method and System for Correction of Optical Satellite Image. U.S. Patent US9,117,276 B2, 25 Agusut 2015.

25. Rosenblatt, F. Principles of Neuro Dynamics; Spartan: New York, NY, USA, 1962.

26. Ahmed, E.A.; Adam, M.E.-N. Estimate of global solar radiation by using artificial neural network in Qena, Upper Egypt. J. Clean Technol. 2013, 1, 148-150. [CrossRef]

27. Xiu, L.-N.; Liu, X.-N. Current status and future direction of the study on artificial neural network classification processing in remote sensing. Remote Sens. Technol. Appl. 2003, 18, 339-345.

28. Kia, M.; Pirasteh, S.; Pradhan, B.; Mahmud, A.; Sulaiman, W.; Moradi, A. An artificial neural network model for flood simulation using GIS: Johor River Basin, Malaysia. Environ. Earth Sci. 2012, 67, 251-264. [CrossRef]

29. Mishra, V.N.; Rai, P.K.; Mohan, K. Prediction of land use changes based on land change modeler (LCM) using remote sensing: A case study of Muzaffarpur (Bihar), India. J. Geogr. Inst. Jovan Cvijic 2014, 64, 111-127. [CrossRef] 
30. Rokni, K.; Ahmad, A.; Solaimani, K.; Hazini, S. A new approach for surface water change detection: Integration of pixel level image fusion and image classification techniques. Int. J. Appl. Earth Obs. Geoinf. 2015, 34, 226-234. [CrossRef]

31. McClelland, J.L.; Rumelhart, D.E. Explorations in Parallel Distributed Processing; MIT Press: Cambridge, UK, 1988.

32. Rumelhart, D.E.; Hinton, G.E.; Willams, R.J. Learning Internal Representations by Error Propagation. In Parallel Distributed Processing, Explorations in the Microestruture of Cognition. Vol. 1: Foundations; Rumelhart, D.E., McClelland, J.L., Eds.; MIT Press: Cambridge, UK, 1986.

33. Minsky, M.L.; Papert, S.A. Perceptrons, Expanded Edition; MIT Press: Cambridge, UK, 1969.

34. Lee, S.; Yang, M.; Lee, C.W. Time Series Analysis of Area of Deltaic Barrier Island in Nakdong River Using Landsat Satellite Image. J. Korean Soc. Surv. Geod. Photogramm. Cartogr. 2016, 34, 457-469. [CrossRef]

35. Robert, H. Cenozoic geological and plate tectonic evolution of SE Asia and the SW Pacific: Computer-based reconstruction, model and animations. J. Asian Earth Sci. 2002, 20, 353-431.

36. Mulyana, A.R. Mapping of Disaster Prone Areas Mount Sinabung, Center for Volcanology and Geological Hazard Mitigation; Ministry of Energy and Mineral Resources Indonesia: Jakarta, Indonesia, 2010.

37. Lee, C.W.; Lu, Z.; Jin, W.K. Monitoring Mount Sinabung in Indonesia Using Multi-Temporal InSAR. Korean J. Remote Sens. 2017, 33, 37-46. [CrossRef]

(C) 2017 by the authors. Licensee MDPI, Basel, Switzerland. This article is an open access article distributed under the terms and conditions of the Creative Commons Attribution (CC BY) license (http:/ / creativecommons.org/licenses/by/4.0/). 